\author{
Tomasz TRZEPIECIŃSKI ${ }^{1}$ \\ Irena NOWOTYŃSKA ${ }^{2}$ \\ Feliks STACHOWICZ ${ }^{3}$ \\ Tomasz MALINOWSKI ${ }^{4}$ \\ Tomasz PIEJA ${ }^{5}$
}

\title{
THERMOVISUAL ANALYSIS OF STAINLESS STEEL SHEET HEATING
}

\begin{abstract}
The purpose of warm forming is to reduce the deformation resistance, and therefore the formation of products at reduced pressures. A key problem associated with warm sheet metal forming is uniform heating of the material to a required temperature. This task is carried out mostly by using resistance heating plates. The article presents the results of the analysis of the thermal state of a heating plate for induction heating of an AMS 5604 stainless steel sheet. To determine the temperature distribution on the sheet surface an FLIR P 640 thermal imaging camera was used. It was found that the temperature difference on the outer surface of sheets preheated to the temperature of $900^{\circ} \mathrm{C}$ was about $300^{\circ} \mathrm{C}$. A large difference in the temperature on the outer surface of the sheet means that the analysed device cannot be successfully used in the heating process of stainless steel sheets. After the application of a layer of graphite on the sheet surface to increase the emissivity, areas of low emissivity as a result of graphite detachment from the sheet surface were observed.
\end{abstract}

Keywords: emissivity, heating plate, thermovision, stainless steel sheet

\section{Introduction}

AMS alloys find numerous applications, especially in the aerospace industry and in the electronics and automotive industry, thanks to their excellent corrosion resistance, good mechanical properties at high temperature and good surface appearance. Sheets made of this type of alloy can be formed with an application of metal forming methods. Because of the low elongation capacity the

\footnotetext{
${ }^{1}$ Autor do korespondencji/corresponding author: Tomasz Trzepieciński, Rzeszow University of Technology, 12 Powstańców Warszawy Ave., 35-959 Rzeszów, tel.: (17) 865 1714, e-mail: tomtrz@prz.edu.pl

2 Irena Nowotyńska, Rzeszow University of Technology, e-mail: i_nowot@prz.edu.pl

${ }^{3}$ Feliks Stachowicz, Rzeszow University of Technology, e-mail: stafel@prz.edu.pl

${ }^{4}$ Tomasz Malinowski, Pratt \& Whitney Rzeszów, e-mail: Tomasz.Malinowski@wskrz.com

${ }^{5}$ Tomasz Pieja, Pratt \& Whitney Rzeszów, e-mail: Tomasz.Pieja@wskrz.com
} 
plastic working of such sheets is not an easy task. At the same time the development of techniques using advanced sheet-forming processes of stainless steel [1-4] is still ongoing as the plasticity of stainless steel in various process conditions has not been thoroughly investigated yet. In the case of cold forming of this type of sheet it is impossible to get enough high strains to produce components with complex shapes but the proper softening treatment of such alloys can greatly improve it. The temperature of plastic working can change as above a certain temperature when the process of intensive ageing of the supersaturated alloy takes place, leading at the same time to a strong decrease in plasticity and strength of the supersaturated alloy [5-6]. Therefore, it is important to determine the parameters of the treatment at higher temperature so as to avoid ageing of the material during the process and to obtain low stress in plastic forming. To form plastic parts from difficult deformable materials warm working is increasingly used. The literature covering the development of warm forming relates primarily to aluminium and magnesium alloys, and there are fewer data on alloys of titanium and steel.

The behaviour and formability of sheet steel in the forming processes are the subject of few studies. Takuda et al. [2] conducted experiments on warm forming of drawpieces of austenitic stainless steel and determined the distribution of martensite in the samples. Iguchi and Ujiro [4] studied the influence of temperature gradients on the plasticity of ferritic stainless steel. Stachowicz et al. [1] examined the impact of temperature on the mechanical properties (such as yield point) and on springing in the V-bend test for corrosion-resistant steel. Yi et al. [7] conducted a study on warm forming of drawpieces of AZ31 and ZE10 magnesium alloys. Similar studies were conducted by Mekonen et al. [8] for AZ31 and ZE10 alloys and a constitutive relationship describing the behaviour of the material was developed. Palumbo et al. [9], Ren et al. [10] and Lee et al. [11] studied the effects of punch velocity and tool temperature on pressing depth for AZ31 magnesium alloy. Zhang et al. [12] studied, inter alia, the impact of grease and the clearance between the punch and die block on the press formability of AZ31 alloy. Chang et al. [13] conducted simulations using the finite element method for warm forming process of AZ31 alloy drawpieces and obtained compliance with the results of experimental studies. Similar studies were conducted by Lee et al. [14]. The formability of Al-Mg sheet can be greatly improved by warm forming [15]. The potential process for mass production of magnesium alloy components was investigated by Wang e al. [16]. Bagheriasl et al. [17] studied the effect of tool temperature on the press formability of aluminium alloys. Laurent et al. [18] invesigated the warm deep drawing of circular AA5754-O aluminium alloy blanks using specially designed equipment. Temperature-dependent anisotropic model for the material was implemented in the ABAQUS/Standard program. Extensive experimental and numerical studies on drawpieces formation at different tool temperatures relate mainly to magnesium and aluminium alloys [14, 19-22]. 
In spite of research on various process parameters and their influence on the behaviour of different metals and alloys there are no exact data related to corrosion-resistant alloys. Therefore, in order to obtain more detailed information about the behaviour of stainless steel in the process of shaping, especially at high temperatures, there is a need for experimentation in this area. The article presents the analysis of the thermal state of a heating plate for induction heating of an AMS 5604 stainless steel sheet. To determine the temperature distribution on the sheet surface a thermal imaging camera was used.

\section{Methods}

In order to prove the applicability of the induction heating process of stainless steel sheets for sheet metal forming thermovisual investigations were carried out. We analysed the thermal state of a heating plate which was part of an industrial device (fig. 1) for induction heating of sheet metals. The thermovisual analysis of the plate state was carried out during heating of an AMS 5604 stainless steel sheet (chemical composition: $\mathrm{Cr}$ 16.5, Ni 4.0, $\mathrm{Cu} 4.0, \mathrm{Mn}$ 1.0, Mo 0.5, Si 1.0, Nb 0.3, C 0.07 wt. pct.), with a thickness of $1.6 \mathrm{~mm}$. AMS 5604 alloy is a martensitic stainless steel that provides an outstanding combination of good corrosion resistance and high strength, and is used extensively in the aerospace industry for various aircraft components.

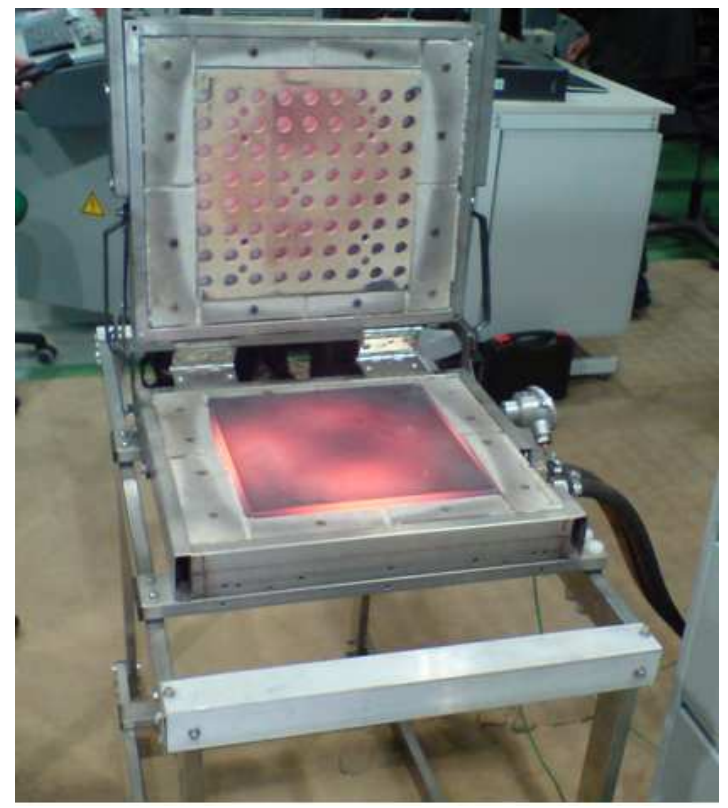

Fig. 1. Device for induction heating of sheet metals 
A steel plate was preheated to $900^{\circ} \mathrm{C}$ for a sheet metal forming operation. Distributions of temperature on the sheet surface were determined using an FLIR P 640 thermal imaging camera with sensitivity spanning the 8 to $14 \mu \mathrm{m}$ wavelength range. Thermographic measurements were performed in stationary state in a conditioned room. The measurement conditions were as follows: ambient temperature $16^{\circ} \mathrm{C}$, apparent temperature $17^{\circ} \mathrm{C}$, relative humidity $60 \%$, plate emissivity 0.98 .

\section{Results and discussion}

The temperature gradient on the outer sheet surface area Ar1 (fig. 2) was about $300^{\circ} \mathrm{C}$ (fig. 3). A large difference in the temperature on the outer surface of the sheet means that the analysed device cannot be successfully used in the heating process of stainless steel sheets. The lowest temperature was observed in the corners of the analysed area Ar1. This area was nearly equal to the operating area of the heating plate. In the middle part of area Ar1 the temperature distribution was quite uniform, so it is suggested that to ensure uniform distribution of temperature in the heating plate area should be increased.

To increase the emissivity of the sheet the outer sheet surface was covered by a graphite layer. The areas of low emissivity (fig. 4) were a result of graphite detachment from the sheet surface. The distribution of the temperature reflected from the surfaces surrounding the analysed object is shown in the fig. 4. To obtain a true temperature field the thermovisual measurements at near-ambient conditions must take into account the radiation of surroundings. The radiation measured by an infrared camera not only depends on the temperature of the object, but is also a function of its emissivity. The distribution of temperature along the $\mathrm{x}$ - and $\mathrm{y}$-direction (fig. 4) was not satisfactory. The temperature gradient along both directions was close to $100^{\circ} \mathrm{C}$ (figs. 5 and 6).

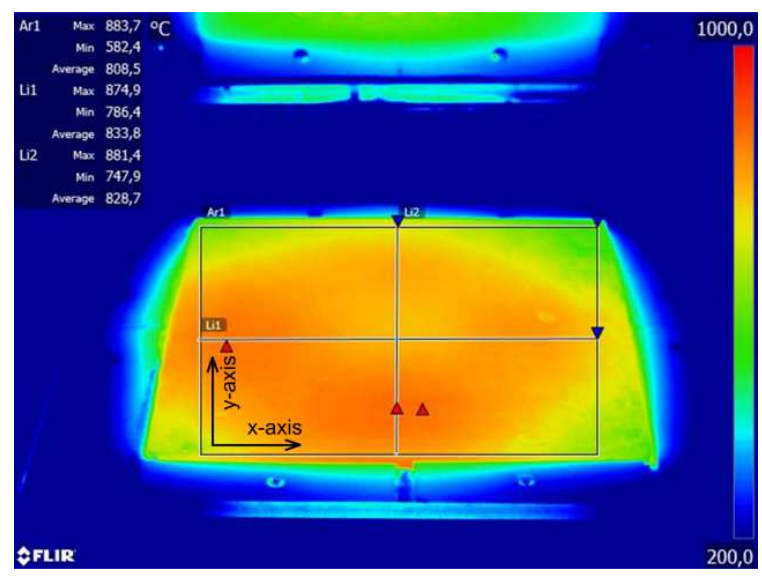

Fig. 2. Thermogram of heating plate 
Although atmospheric infrared radiation can be neglected at short distances from the target surface, infrared temperature measurements are perturbed by the surrounding radiation $[23,24]$. The heating efficiency of the induction plate depends on the geometry of the inductor and the position of the magnetic field relative to the workpiece. Furthermore the distance between inductor and preheated sheet also influences the efficiency of the heating device.

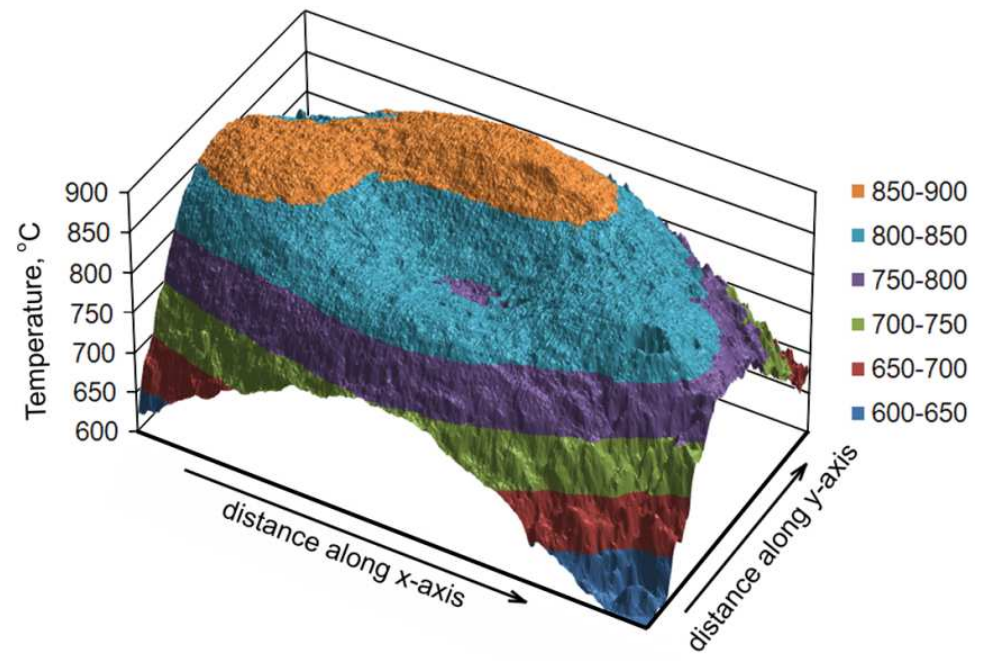

Fig. 3. Temperature distribution in analysed heating plate area (see fig. 2)

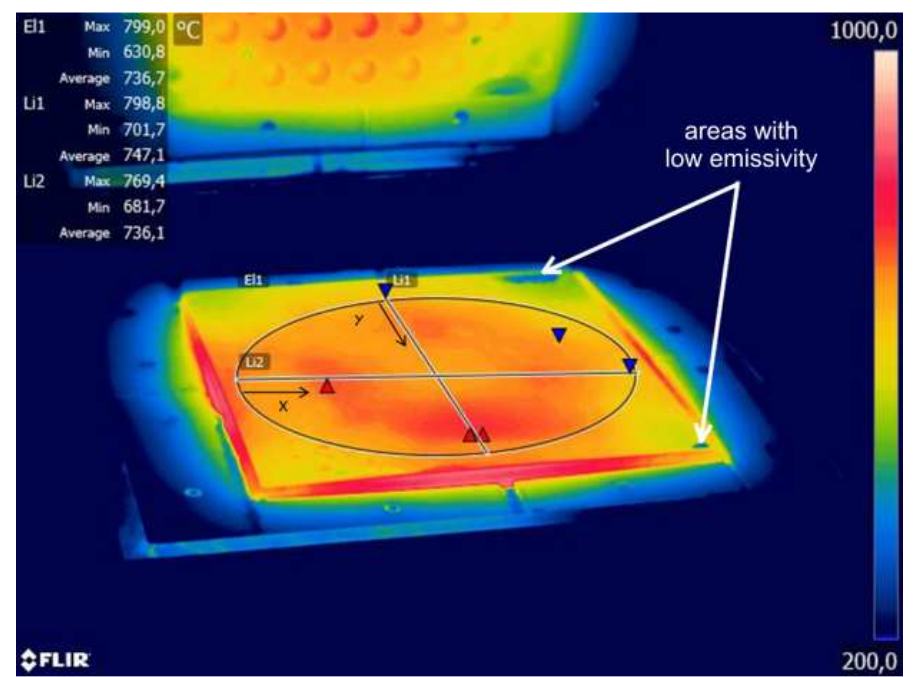

Fig. 4. Thermogram of sheet after the application of a graphite layer on the sheet surface 


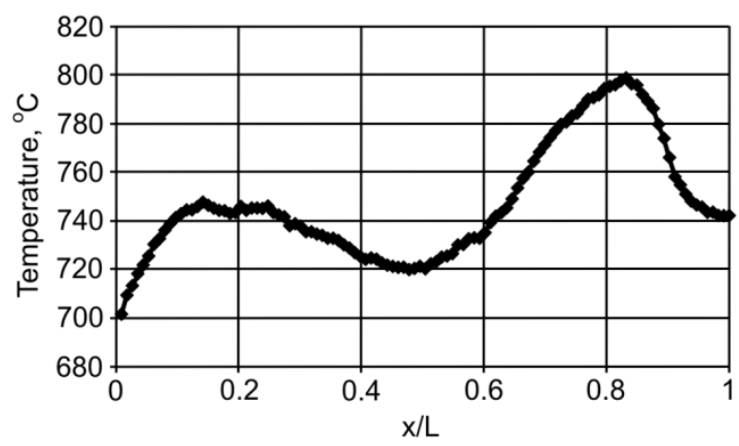

Fig. 5. Temperature distribution in outer sheet surface along the x-direction

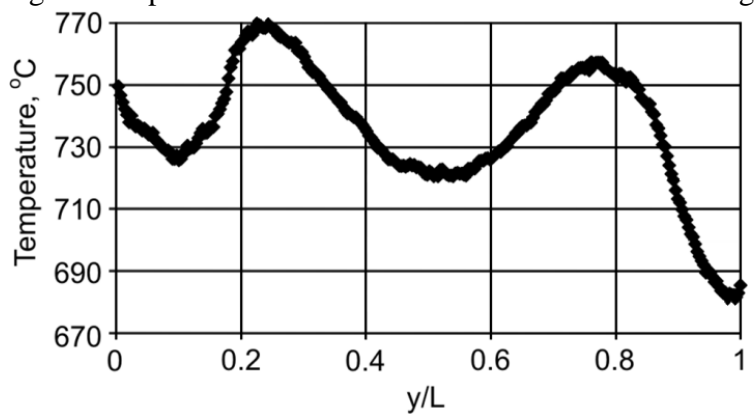

Fig. 6. Temperature distribution in outer sheet surface along the y-direction

\section{Conclusions}

The thermovisual technique can be successfully used instead of standard sensors for measuring both the sheet surface and heating plate temperature. The distribution of temperature can be recorded at a certain point on a chosen line on the sheet profile or area.

The temperature difference on the outer surface of sheets preheated to a temperature of $900^{\circ} \mathrm{C}$ was about $300^{\circ} \mathrm{C}$. After the application of a layer of graphite on the sheet surface to increase the emissivity, the temperature gradient was smaller and was close to $100^{\circ} \mathrm{C}$. Observed areas of low emissivity of sheet metal were a result of graphite detachment from the sheet surface. A large difference in the temperature on the outer surface of the sheet means that the analysed device cannot be successfully used in the heating process of stainless steel sheets.

\section{Literatura}

[1] Stachowicz F., Trzepieciński T., Pieja T.: Warm forming of stainless steel sheet, Arch. Civ. Mech. Eng., 10 (2010) 85-94. 
[2] Takuda H., Mori K., Masachika T., Yamazaki E., Watanabe Y.: Finite element analysis of the formability of an austenitic stainless steel sheet in warm deep drawing, J. Mater. Proc. Tech., 143-144 (2003) 242-248.

[3] Lonardelli I., Bosetti P., Bruschi S., Molinari A.: On the formability and microstructural characteristics of AISI 301 parts formed by single-point incremental forming, Key Eng. Mater., 473 (2011) 869-874.

[4] Iguchi T., Ujiro T.: Effect of imposing temperature gradient in stretch forming process for ferritic stainless steel sheets, AIP Conf. Proc., 1252 (2010) 1193-1200.

[5] Shankar V., Bhanu Sankara Rao K., Mannan S.L.: Microstructure and mechanical properties of Inconel 625 superalloy, J. Nucl. Mater., 288 (2001) 222-232.

[6] Shankar V., Valsan M., Bhanu Sankara Rao K., Mannan S.L.: Room temperature tensile behavior of service exposed and thermally aged alloy 625, Scripta Mater., 44 (2001) 2703-2711.

[7] Yi S., Bohlen J., Heinemann F., Letzig D.: Mechanical anisotropy and deep drawing behaviour of AZ31 and ZE10 magnesium alloy sheets, Acta Mater., 58 (2010) 592-605.

[8] Mekonen M.N., Steglich D., Bohlen J., Letzig D., Mosler J.: Mechanical characterization and constitutive modeling of Mg alloy sheets, Mat. Sci. Eng. A-Struct., 540 (2012) 174-86.

[9] Palumbo G., Sorgente D., Tricarico L., Zhang S.H., Zheng W.T.: Numerical and experimental investigations on the effect of the heating strategy and the punch speed on the warm deep drawing of magnesium alloy AZ31, J. Mater. Proc. Tech., 191 (2007) 342-346.

[10] Ren L.M., Zhang S.H., Palumbo G., Sorgente D., Tricarico L.: Numerical simulation on warm deep drawing of magnesium alloy AZ31 sheets, Mat. Sci. Eng. AStruct., 499 (2009) 40-44.

[11] Lee Y.S., Kwon Y.N., Kang S.H., Kim S.W., Lee J.H.: Forming limit of AZ31 alloy sheet and strain rate on warm sheet metal forming, J. Mater. Proc. Tech., 201 (2008) 431-435.

[12] Zhang S.H., Zhang K., Xu Y.C., Wang Z.T., Xu Y., Wang Z.G.: Deep-drawing of magnesium alloy sheets at warm temperatures, J. Mater. Proc. Tech., 185 (2007) 147-151.

[13] Chang Q.F., Li D.Y., Peng Y.H., Zeng X.Q.: Experimental and numerical study of warm deep drawing of AZ31 magnesium alloy sheet, Int. J. Mach. Tool. Manuf., 47 (2007) 436-43.

[14] Lee Y.S., Kim M.C., Kim S.W., Kwon Y.N., Choi S.W., Lee J.H.: Experimental and analytical studies for forming limit of AZ31 alloy on warm sheet metal forming, J. Mater. Proc. Tech., 187-188 (2007) 103-107.

[15] Kurukuri S., van den Boogaard A.H., Miroux A., Holmedal B.: Warm forming simulation of Al-Mg sheet. J. Mater. Proc. Tech., 209 (2009) 5636-5645.

[16] Wang W., Huang L., Tao K., Chen ., Wei X.: Formability and numerical simulation of AZ31b magnesium alloy sheet in warm stamping process, Mater. Des., 87 (2015) 835-844.

[17] Bagheriasl R., Worswick M., McKinley J., Simha H.: An effective warm forming process; numerical and experimental study, Int. J. Mater. Form., 3 (2010) 219-222. 
[18] Laurent H., Coer J., Manach P.Y., Oliveira M.C., Menezes L.F.: Experimental and numerical studies on the warm deep drawing of an Al-Mg alloy, Int. J. Mech. Sci., 93 (2015) 59-72.

[19] Zhang K.F., Yin D.L., Wu D.Z.: Formability of AZ31 magnesium alloy sheets at warm working conditions, Int. J. Mach. Tool. Manu., 46 (2006) 1276-1280.

[20] Takuda H., Mori K., Masuda I., Abe Y., Matsuo M.: Finite element simulation of warm deep drawing of aluminium alloy sheet when accounting for heat conduction, J. Mater. Proc. Tech., 120 (2002) 412-418.

[21] Li D., Ghosh A.K.: Biaxial warm forming behavior of aluminum sheet alloys, J. Mater. Proc. Tech., 145 (2004) 281-293.

[22] Lee M.H., Kim H.Y., Kim H.J., Choi Y.C., Oh S.I.: Numerical modeling of magnesium alloy sheet metal forming at elevated temperature, AIP Conf. Proc., 908 (2007) 569-574.

[23] Datcu S., Ibos L., Candau Y., Mattei S.: Improvement of building wall surface temperature measurements by infrared thermography, Infrared Phys. Techn., 46 (2005) 451-467.

[24] Bianchi F., Pisello A.L., baldinelli G., Asdrubali F.: Infrared thermography assessment of thermal bridges in building envelope: Experimental validation in a test room setup, Sustainability, 6 (2014) 7107-7120.

\section{ANALIZA TERMOWIZYJNA PODGRZEWANIA BLACHY STALOWEJ NIERDZEWNEJ}

\section{Streszczenie}

Celem obróbki plastycznej na półgorąco jest obniżenie oporu plastycznego, a zatem kształtowanie wyrobów przy obniżonych naciskach. Kluczowym problemem związanym z kształtowaniem blach na półgorąco jest równomierne podgrzanie materiału do wymaganej temperatury. Zadanie to jest realizowane najczęściej za pomocą oporowych płyt grzewczych. W pracy przedstawiono wyniki analizy stanu termicznego płyty grzejnej do indukcyjnego podgrzewania blach ze stali nierdzewnej AMS 5604. Do określenia rozkładu temperatury na powierzchni blachy wykorzystano kamerę termowizyjną FLIR P 640. Stwierdzono, że gradient temperatury w materiale podgrzewanym do temperatury $900^{\circ} \mathrm{C}$ wynosi około $300^{\circ} \mathrm{C}$. Tak duża różnica w temperaturze na powierzchni płyty powoduje, że analizowane urządzenie nie może być z powodzeniem wykorzystane $\mathrm{w}$ procesie podgrzewania blach stalowych nierdzewnych. Po naniesieniu na powierzchnię blachy warstwy grafitu w celu zwiększenia emisyjności zaobserwowano obszary o niskiej emisyjności powstałe w wyniku odklejenia grafitu od powierzchni blachy.

Słowa kluczowe: emisyjność, płyta grzejna, termowizja, blacha stalowa nierdzewna

DOI: $10.7862 / \mathrm{rm} .2015 .36$

Otrzymano/received: 4.11.2015 r.

Zaakceptowano/accepted: 11.12.2015 r. 